NASA/TM-2003-212394

\title{
Study of Unsteady Flows With Concave Wall Effect
}

Chi R. Wang

Glenn Research Center, Cleveland, Ohio 
Since its founding, NASA has been dedicated to the advancement of aeronautics and space science. The NASA Scientific and Technical Information (STI) Program Office plays a key part in helping NASA maintain this important role.

The NASA STI Program Office is operated by Langley Research Center, the Lead Center for NASA's scientific and technical information. The NASA STI Program Office provides access to the NASA STI Database, the largest collection of aeronautical and space science STI in the world. The Program Office is also NASA's institutional mechanism for disseminating the results of its research and development activities. These results are published by NASA in the NASA STI Report Series, which includes the following report types:

- $\quad$ TECHNICAL PUBLICATION. Reports of completed research or a major significant phase of research that present the results of NASA programs and include extensive data or theoretical analysis. Includes compilations of significant scientific and technical data and information deemed to be of continuing reference value. NASA's counterpart of peerreviewed formal professional papers but has less stringent limitations on manuscript length and extent of graphic presentations.

- TECHNICAL MEMORANDUM. Scientific and technical findings that are preliminary or of specialized interest, e.g., quick release reports, working papers, and bibliographies that contain minimal annotation. Does not contain extensive analysis.

- CONTRACTOR REPORT. Scientific and technical findings by NASA-sponsored contractors and grantees.
- CONFERENCE PUBLICATION. Collected papers from scientific and technical conferences, symposia, seminars, or other meetings sponsored or cosponsored by NASA.

- SPECIAL PUBLICATION. Scientific, technical, or historical information from NASA programs, projects, and missions, often concerned with subjects having substantial public interest.

- TECHNICAL TRANSLATION. Englishlanguage translations of foreign scientific and technical material pertinent to NASA's mission.

Specialized services that complement the STI Program Office's diverse offerings include creating custom thesauri, building customized databases, organizing and publishing research results ... even providing videos.

For more information about the NASA STI Program Office, see the following:

- Access the NASA STI Program Home Page at http://www.sti.nasa.gov

- E-mail your question via the Internet to help@sti.nasa.gov

- Fax your question to the NASA Access Help Desk at 301-621-0134

- Telephone the NASA Access Help Desk at 301-621-0390

- Write to:

NASA Access Help Desk

NASA Center for AeroSpace Information 7121 Standard Drive

Hanover, MD 21076 
NASA/TM-2003-212394

\section{Study of Unsteady Flows With Concave Wall Effect}

Chi R. Wang

Glenn Research Center, Cleveland, Ohio

Prepared for the

21st Applied Aerodynamics Conference

sponsored by the American Institute of Aeronautics and Astronautics Orlando, Florida, June 23-26, 2003

National Aeronautics and

Space Administration

Glenn Research Center 
This report is a formal draft or working paper, intended to solicit comments and ideas from a technical peer group.

This report contains preliminary findings, subject to revision as analysis proceeds.

This report is a preprint of a paper intended for presentation at a conference. Because of changes that may be made before formal publication, this preprint is made available with the understanding that it will not be cited or reproduced without the permission of the author.

Available from

NASA Center for Aerospace Information 7121 Standard Drive

Hanover, MD 21076
National Technical Information Service 5285 Port Royal Road Springfield, VA 22100 


\title{
Study of Unsteady Flows With Concave Wall Effect
}

\author{
Chi R. Wang \\ National Aeronautics and Space Administration \\ Glenn Research Center \\ Cleveland, Ohio 44135
}

\begin{abstract}
$\underline{\text { ABSTRACT }}$
This paper presents computational fluid dynamic studies of the inlet turbulence and wall curvature effects on the flow steadiness at near wall surface locations in boundary layer flows. The time-stepping RANS numerical solver of the NASA Glenn-HT RANS code and a one-equation turbulence model, with a uniform inlet turbulence modeling level of the order of $10 \%$ of molecular viscosity, were used to perform the numerical computations. The approach was first calibrated for its predictabilities of friction factor, velocity, and temperature at near surface locations within a transitional boundary layer over concave wall. The approach was then used to predict the velocity and friction factor variations in a boundary layer recovering from concave curvature. As time iteration proceeded in the computations, the computed friction factors converged to their values from existing experiments. The computed friction factors, velocity, and static temperatures at near wall surface locations oscillated periodically in terms of time iteration steps and physical locations along the span-wise direction. At the upstream stations, the relationship among the normal and tangential velocities showed vortices effects on the velocity variations. Coherent vortices effect on the velocity components broke down at downstream stations. The computations also predicted the vortices effects on the velocity variations within a boundary layer flow developed along a concave wall surface with a downstream recovery flat wall surface. It was concluded that the computational approach might have the potential to analyze the flow steadiness in a turbine blade flow.
\end{abstract}

\section{INTRODUCTION}

The Gas Turbine Branch of NASA Glenn Research Center has been developing the NASA Glenn-HT CFD Code for the prediction of gas turbine blade surface heat transfer. The Code used time-stepping RANS computational methods and two equation turbulence models to perform the surface heat transfer computations. Wall curvature and inlet turbulence play important roles in the flow development over a turbine airfoil. This paper presents the approach and results of using the RANS numerical solver and a One-Equation Turbulence Model to model the effects of inlet turbulence level and wall curvature on flow steadiness at locations near wall surface.

The author previously proposed ${ }^{1}$ to use the RANS solver ${ }^{2}$ and a version of One-Equation Turbulence $\mathrm{Model}^{3}$ to analyze the vortices effects on flow properties with surface coolant injection into a boundary layer flow. The author then used the approach to perform a preliminary study ${ }^{4}$ of vortices effects on flow with the influence of concave wall curvature. The previous studies ${ }^{1,4}$ showed that the computational approach, as time iteration proceeded, could predict the experimental friction factors and span-wise velocity variations in boundary layer flows with vortex structures. The author reports here a study of using an existing computational approach ${ }^{1,4}$ to capture the inlet turbulence and wall curvature effects on the flow steadiness at near wall surface locations in boundary layer flows. The approach was first calibrated according to the experiments ${ }^{5}$ of transitional boundary layer on a heated concave wall.

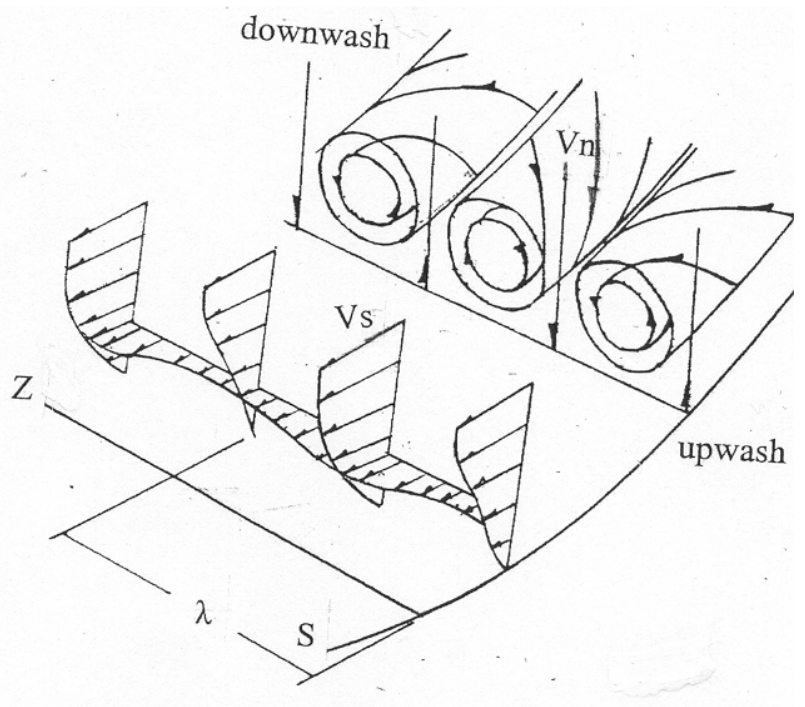

Fig 1 Vortices induced inflection velocity profiles ${ }^{5}$ 
The experiments measured the velocity and temperature variations to investigate the Taylor-Gortler vortices occurrence within the boundary layer flow. When vortices occur, they produce cross-span and cross-stream inflection point velocity profile, Figure 1, and the flow can be steady, transitional, or unsteady. The surface temperature measurements ${ }^{5}$, Figure 2, showed vortices also induced cross-span temperature variations. This author used some of the existing experimental results to calibrate the numerical method.

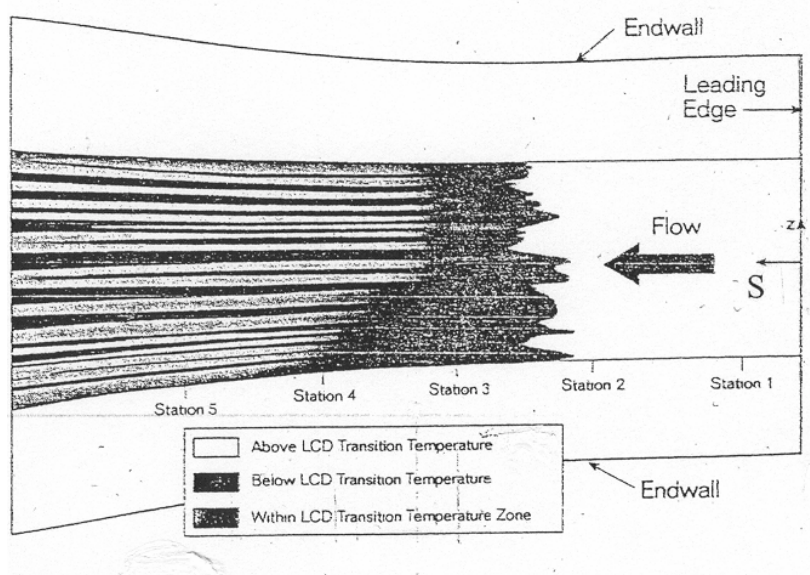

Fig 2 Vortices induced span-wise temperature profile ${ }^{5}$

As a preliminary step to test the approach for analyzing the steadiness of turbine blade flow, the approach was used to predict the velocity and skin friction variations from other experiments ${ }^{6}$. The experiments measured velocities and friction factors of a boundary layer over a concave wall surface followed with a flat recovery wall surface. The velocity measurements showed vortices establishment and vortices effect on boundary layer flow development. This author tested the computational approach to predict some of the velocity measurements.

Time stepping numerical computations were performed with specified inlet turbulence parameter, downstream pressure, computational domains and computational grids. The computed friction factors and the velocities and temperatures at near surface locations were compared with their values from the existing experiments. The three dimensional velocity and temperature variations were investigated in terms of time iteration steps as the computed friction factors converged to their experimental values. The study concluded that this computational approach could be improved for unsteady turbine blade boundary layer flow analysis.

\section{NOMENCLATURE}

\section{Dimensionless Symbols}

$\mathrm{C}_{\mathrm{f}}$ friction factor

$\mathrm{n}$ number of time iteration steps

$\mathrm{N}$ distance from the wall surface

$\mathrm{p}_{\mathrm{d}} \quad$ exit static pressure

$\mathrm{S}$ stream-wise coordinate

$\mathrm{T}$ static temperature

$\mathrm{V}_{\mathrm{n}}$ normal velocity along $\mathrm{N}$ direction

$\mathrm{V}_{\mathrm{s}}$ tangential velocity along $\mathrm{S}$ direction

$\mathrm{Z}$ span-wise coordinate

$\lambda \quad$ velocity profile wave length

$\chi_{\mathrm{i}} \quad$ inlet turbulence parameter

\section{$\underline{\text { Reference Conditions }}$}

h $\quad 0.375 \mathrm{ft}$

$\mathrm{p}_{\mathrm{r}} \quad 14.7 \mathrm{psia}$

$\mathrm{T}_{\mathrm{r}} \quad 535^{\circ} \mathrm{R}$

$\mathrm{V}_{\mathrm{r}} \quad 58 \mathrm{ft} / \mathrm{sec}$

$\rho_{\mathrm{r}} \quad$ density at $\mathrm{T}_{\mathrm{r}}$ and $\mathrm{P}_{\mathrm{r}}$

$v$ molecular kinematic viscosity at $T_{\mathrm{r}}$

$\mu \quad$ molecular viscosity

\section{RANS COMPUTATIONS}

The author used the RANS numerical solver of the NASA Glenn-HT code to perform the numerical computations. The solver used a time-stepping numerical scheme ${ }^{7}$ to solve the three-dimensional, compressible, turbulent timedependent Navier-Stokes equations. An explicit four stage Runge-Kutta numerical scheme ${ }^{2}$ and fourth order cellcenter spatial discretization scheme were used for the present computations. The Numerical solutions of the Navier-Stokes equations and the One-Equation turbulence model were advanced in time using a local time $\operatorname{step}^{2}, \Delta \mathrm{t}$. This time step accounted for both the convective $\left(\Delta \mathrm{t}_{\mathrm{c}}\right)$ and diffusive contribution $\left(\Delta \mathrm{t}_{\mathrm{d}}\right)$ according to $\Delta \mathrm{t}=\mathrm{C}_{0}\left(\Delta \mathrm{t}_{\mathrm{c}} \mathrm{X}\right.$ $\left.\Delta \mathrm{t}_{\mathrm{d}}\right) /\left(\Delta \mathrm{t}_{\mathrm{c}}+\Delta \mathrm{t}_{\mathrm{d}}\right)$. The mathematical expressions for $\Delta \mathrm{t}_{\mathrm{c}}, \Delta \mathrm{t}_{\mathrm{d}}$ and stability control could be found in previous work ${ }^{2} . \mathrm{C}_{0}$ was a constant and was similar to Courant-FriedrichsLewy number. This author assigned a constant value of 1 to $\mathrm{C}_{0}$ in the computations. The computational domains and corresponding computational grid configurations, turbulence model, and boundary conditions were described in the following.

\section{Computational Domains and Grids}

The physical domain used for the method calibration was chosen according to the test section in the experiments ${ }^{5}$. The test section was a rectangular turning duct. The height of the test section was $0.375 \mathrm{ft}$ ( $\mathrm{h}$ in this paper) and 
test section had a high aspect ratio (width/height $=5.6$ ). The radius of the concave wall surface was $3.18 \mathrm{ft}(8.5 \mathrm{~h})$. The duct lower wall was adjusted to develop a boundary layer flow along the concave wall surface. The length of the concave wall surface extended over an angle of 79 degrees and the wall length was $11.75 \mathrm{~h}$. The measurements were made within a small center region of the upper concave wall. Thus, this author chose a physical domain, Figure 3, corresponding to the upper half of the turning duct for the computations.

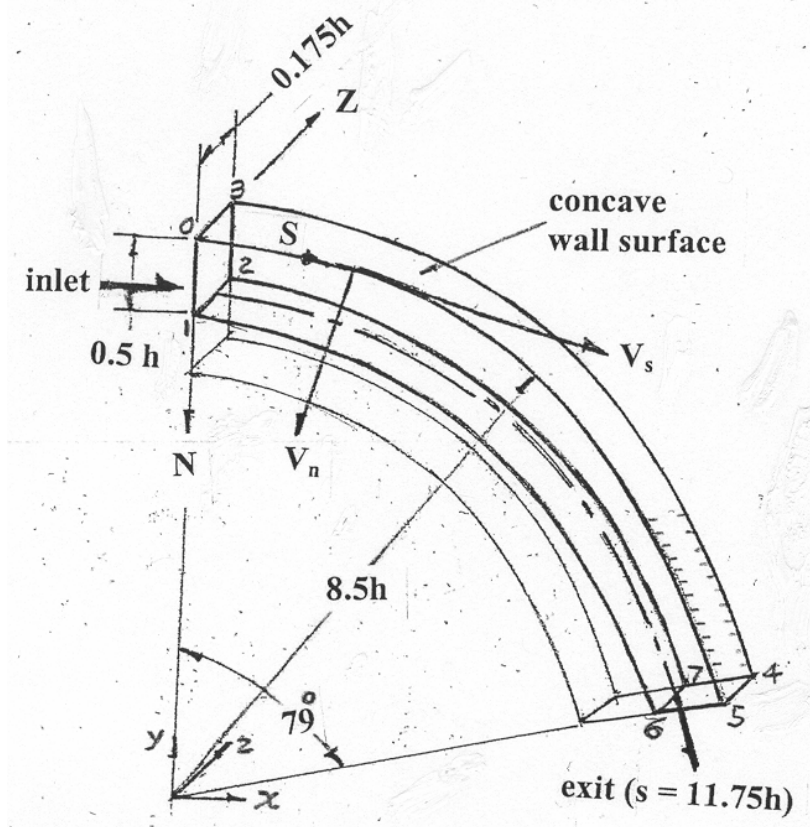

Fig 3 Schematic of domain, 0-3-4-5-6-7-2-1, for method calibration.

Although the domain size along the $\mathrm{Z}$ direction was small $(0.175 \mathrm{~h})$, the size enclosed the domain of velocity measurements in the experiments ${ }^{5}$. Gridgen software was used to generate the computational grid. A single block structured computational grid, with grid point dimensions of 173,73 , and 57 along $\mathrm{S}, \mathrm{N}$ and $\mathrm{Z}$ directions, was first used in the computations. The first grid point along the $\mathrm{N}$ direction was at a distance of 0.00005 from the wall surface. This distance was kept the same along the $\mathrm{S}$ direction. The grid point spacing increased gradually to 0.03 at the domain edge $(\mathrm{N}=0.5)$. The grid point spacing along $\mathrm{S}$ direction was stretched from 0.059 at the inlet (S $=0)$ to 0.18 at the exit $(S=11.75)$. The grid point spacing was uniform along $\mathrm{Z}$ direction. To study the grid effect on the computations, the computations were repeated with a grid point dimension of 205, 61, and 57. The first grid point along $\mathrm{N}$ direction was at $\mathrm{N}=0.0001$ and the grid point spacing was stretched to 0.03 at the $\mathrm{N}=0.5$ location. The grid point spacing along the $\mathrm{S}$ direction was stretched from 0.059 at the inlet to 0.09 at the exit. The grid point spacing was uniform along $\mathrm{Z}$ direction.

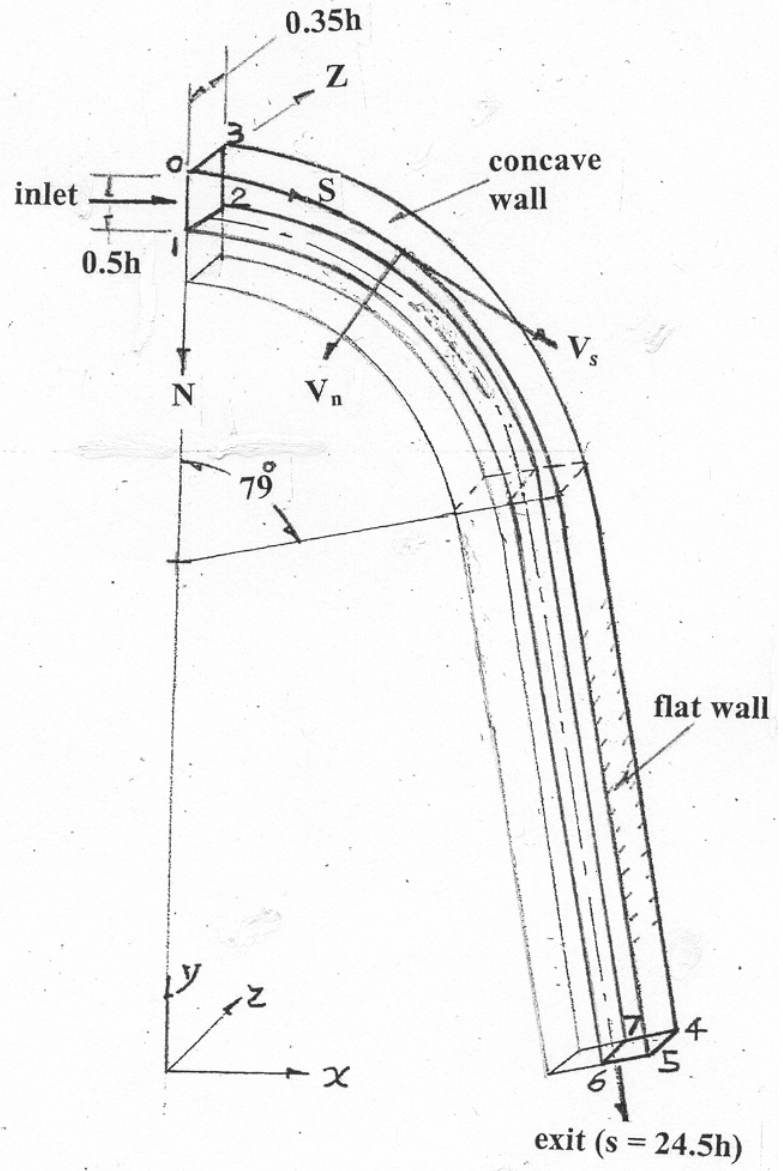

Fig 4 Schematic of domain, 0-3-4-5-6-7-2-1, for method application.

For the method application, the physical domain, Figure 4, was chosen according to the geometry of the test section in existing experiments ${ }^{6}$. Different from the domain in Figure 3, the concave wall surface was followed with a flat wall surface. The flat wall surface was tangent to the concave wall surface at the wall junction. The length of the flat wall was $12.74 \mathrm{~h}$. The domain size along the $\mathrm{Z}$ direction had been increased to $0.35 \mathrm{~h}$ to enclose the domain of velocity measurement ${ }^{6}$. The computational grid point dimensions were 405,61 , and 37 along the $\mathrm{S}, \mathrm{N}$, and $\mathrm{Z}$ directions. The first grid point, along the $\mathrm{N}$ direction at all $\mathrm{S}$ stations, was 0.0001 from the wall surface. The grid point spacing was stretched to 0.03 at the domain edge $(\mathrm{N}=0.5)$. Along the $\mathrm{S}$ direction, the grid point spacing was 0.03 at the inlet and was stretched to 0.09 at the exit. The grid point spacing was uniform along the $\mathrm{Z}$ direction. 


\section{Turbulence Model}

A one-equation turbulence transport equation, derived from an original turbulence model ${ }^{3}$, was used to model the eddy viscosity. The capability of this model to account for the flow transition with vorticity at a tripping point prompted the use of the model. The turbulence transport equation was written in a form ${ }^{1}$ suitable for its implementation in the numerical scheme used in the Glenn-HT RANS code. The mathematical expressions of the turbulence model were summarized in the APPENDIX section of the paper. It was further assumed that each surface grid point along the span-wise direction beneath a field point acted as an individual tripping point. The transition term in the turbulence model was the summation of the transition terms due to vortices at all span-wise surface grid points. Reynolds analogy was used to relate the turbulence contribution in the energy equation.

\section{$\underline{\text { Boundary Conditions }}$}

The surfaces of the computational domains (Figures 3 and 4) consisted of inlet (0-1-2-3) and exit (4-5-6-7) planes, wall surface (0-3-4-5), and symmetry planes $(2-3-4-7,0-$ 1-6-5 and 1-2-7-6). Since a fourth-order cell-center scheme was used for the spatial discretization in the numerical schemes. The numerical computations required flow properties at two phantom cell centers immediately outside of the domain surfaces. These properties were specified with the following approaches.

It was assumed that the cross flow velocity components were zero at the inlet phantom cell centers. Their static pressures and mass flow rates were set to the first interior cell centers' static pressures and mass flow rates computed from previous time iteration. The density and total energy were then computed from the pressure and velocity with isentropic flow relationships. A uniform turbulent eddy viscosity parameter $\chi_{\mathrm{i}}$ (APPENDIX), of the order of 0.1 , was imposed at the inlet phantom cell centers. According to equations (2), (3), and (4) in the APPENDIX, this range of $\chi_{i}$ value gave a uniform inlet eddy viscosity level which was much smaller than the molecular viscosity.

A zero normal pressure gradient was assumed at the wall surface and the linearization approach ${ }^{8}$ was used to calculate the density values at the phantom cell centers next to the wall surface. Non-slip conditions were used to set the velocity and turbulent eddy viscosity at the phantom cell centers. The constant wall temperature condition was used in the computations and the temperature was $4 \%$ larger than the room temperature ${ }^{5,6}$.
Flow symmetry was assumed at the domain surfaces (2-34-7 and 0-1-6-5) along the $\mathrm{Z}$ direction and at the domain surface (1-2-7-6) at $\mathrm{N}=0.5$. The flow properties at the phantom cell centers next to these surfaces were set to their values at the interior cell centers adjacent to the boundary surfaces.

A uniform static pressure was imposed at the exit plane. The other mean flow properties at the down stream phantom cell centers were extrapolated ${ }^{8}$ from their interior values and the exit static pressure. The present author used a downstream static pressure level, $p_{d}=0.96$, for the model calibration and a downstream static pressure, $\mathrm{p}_{\mathrm{d}}=0.93$, for the model application. It was assumed that the turbulent eddy viscosity values at the downstream phantom cell centers were the same as eddy viscosity value at the first interior cell center next to the exit plane.

\section{RESULTS AND DISCUSSIONS}

The computational procedures were performed for four different cases. The domain, grid point dimensions, inlet turbulence parameter, and downstream pressure for each case were listed in Table 1.

\begin{tabular}{|c|c|c|c|c|}
\hline case & $\begin{array}{c}\text { grid points } \\
\mathbf{S}, \mathbf{N}, \mathbf{Z}\end{array}$ & domain & $\begin{array}{c}\text { turbulence } \\
\boldsymbol{\chi}\end{array}$ & $\mathbf{p}_{\mathbf{d}}$ \\
\hline 1 & $173,73,57$ & fig 3 & 0.050 & 0.96 \\
2 & $173,73,57$ & fig 3 & 0.075 & 0.96 \\
3 & $205,61,57$ & fig 3 & 0.075 & 0.96 \\
4 & $405,61,37$ & fig 4 & 0.125 & 0.93 \\
\hline
\end{tabular}

Table 1 Parameters for computational cases

The method calibration was based on the accuracy to predict friction factors from experiments ${ }^{5}$. Three computational cases $(1,2$, and 3$)$ were performed to study the effects of grid point dimensions and inlet turbulence parameter, $\chi_{i}$ on the friction factor computations. With experience from the method calibration, a computational grid and an inlet turbulence parameter, $\chi_{i}=0.125$ were chosen for the method application (case 4). As time iterations advanced to the order of 10,000 , the computed friction factor converged to its experimental value. The computed friction factor and the normal and tangential velocities and static temperature variations at locations near the wall surface were compared with their measurements to access the accuracy of the computational methods. As friction factors converged to their experimental values, the velocity and temperature variations in terms of the time iteration step and spanwise locations were studied for the steadiness of boundary layer flows. 


\section{Method Calibration}

It was assumed that the tangential velocity changed linearly from the wall surface to the first cell center location. The surface friction was computed with $\mu \mathrm{V}_{\mathrm{s}} / \mathrm{N}$ corresponding to the first cell center flow conditions. Skin friction was non-dimensionalized with reference ${ }^{5}$ dynamic pressure $0.5 \rho_{\mathrm{r}} \mathrm{V}_{\mathrm{r}}^{2}$ to get friction factor, $\mathrm{C}_{\mathrm{f}}$. $\mathrm{C}_{\mathrm{f}}$ at $\mathrm{Z} \approx 0$ (near the symmetric plane) from the computations were plotted in figure 5 .

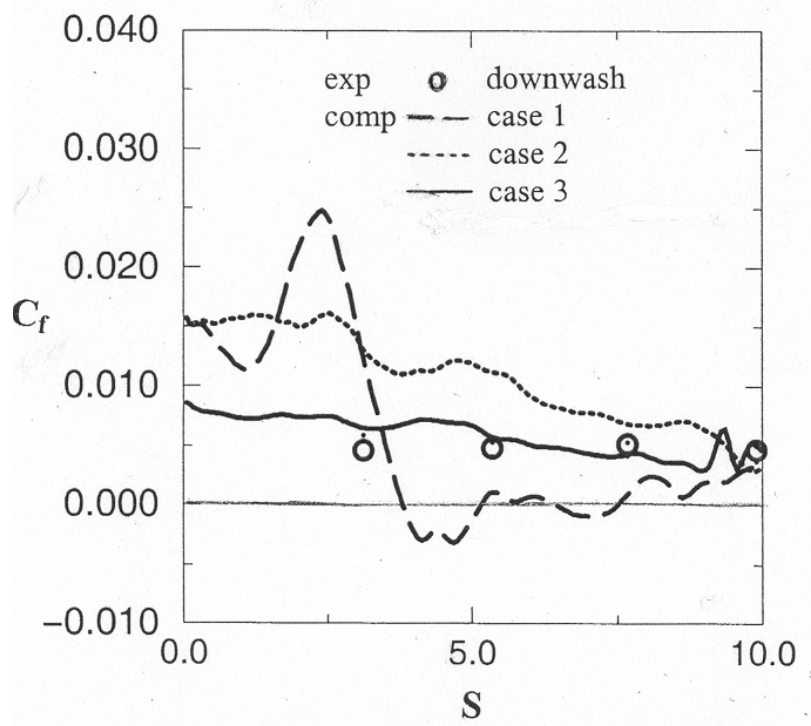

Fig 5 Friction factors at symmetric plane, $\mathrm{z} \approx 0$

Experimental results ${ }^{5}$ of $\mathrm{C}_{\mathrm{f}}$ at four stream-wise stations ( $\mathrm{S}$ $=3.12,5.35,7.68$, and 9.91) were also plotted in this figure to compare them with the computed $\mathrm{C}_{\mathrm{f}}$ at those $\mathrm{S}$ stations. For case $1\left(\chi_{i}=0.05\right)$ and case $2\left(\chi_{i}=0.075\right)$, the computed $\mathrm{C}_{\mathrm{f}}$ values, with a grid point dimensions of 173,73 , and 57 , seemed to converge at time iteration steps $>9000$. The computations, with $\chi_{\mathrm{i}}=0.05$, predicted high $\mathrm{C}_{\mathrm{f}}$ at $\mathrm{S}<3.5$ stations and very small $\mathrm{C}_{\mathrm{f}}$ at $\mathrm{S}>3.5$ stations. The computations, with $\chi_{\mathrm{i}}=0.075$, calculated higher $\mathrm{C}_{\mathrm{f}}$ values than the case with $\chi_{\mathrm{i}}=0.05$, at $\mathrm{S}>3.5$ stations. $\mathrm{C}_{\mathrm{f}}$ at $\mathrm{S}=3.12,5.35,7.68$, and 9.91 from the above two cases did not agree well with the experimental values. With grid dimensions of $205,61,57$ and $\chi_{i}=$ 0.075 (case 3 ), computed $C_{f}$ values seemed to converge at $\mathrm{n}>13700$ and the computed $\mathrm{C}_{\mathrm{f}}$ values at $\mathrm{S}=3.12,5.35$, 7.68 and 9.91 agreed very well with their experimental values. However, computed $\mathrm{C}_{\mathrm{f}}$ values were unsteady and oscillated when the time iteration steps were greater than 13700. Figure 6 showed the $C_{f}$ variations (case 3) along the $\mathrm{S}$ direction at $\mathrm{Z} \approx 0$ and three time iteration steps, $\mathrm{n}=$ 13700,14200 , and 14650 . These results showed that $C_{f}$ at $4.0<\mathrm{S}<6.5$ and $\mathrm{n}=14650$ retained their values at $\mathrm{n}=$ 13700 after significant reductions at $\mathrm{n}=14200$ time iteration.

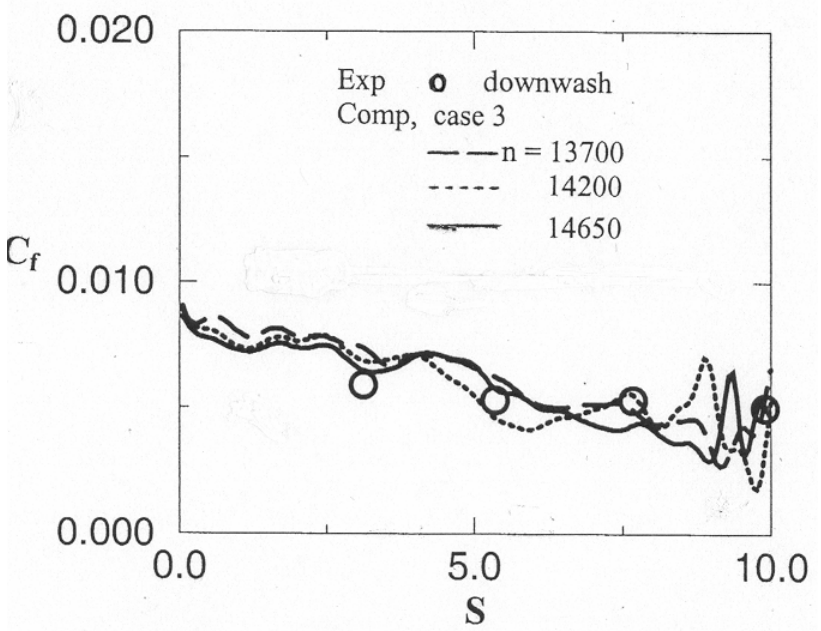

Fig 6 Friction factors at $\mathrm{z} \approx 0$ for 3 iteration steps

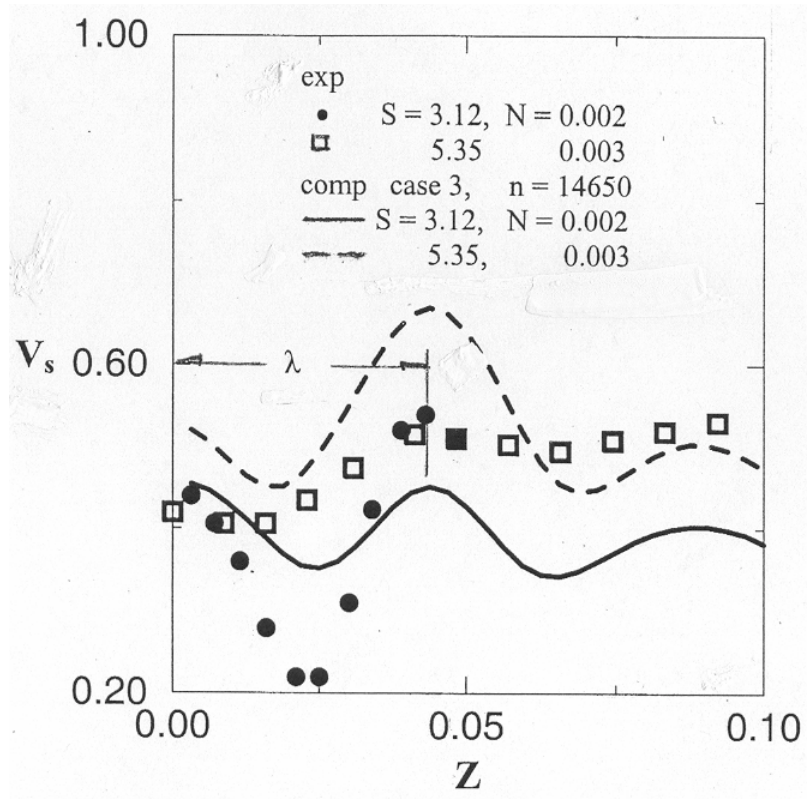

Fig 7 Span-wise variations of $V_{s}$ at $S=3.12$ and 5.35

Existing experiments ${ }^{5}$ measured the velocity at $\mathrm{N}=0.002$ or 0.003 and $\mathrm{Z}<0.1$ locations at $\mathrm{S}=3.12$ and $\mathrm{S}=5.35$ stations. Computed $\mathrm{V}_{\mathrm{s}}$ values (case 3) corresponding to these locations and $n=14650$ were plotted in Figure 7 and they were compared with their measured values. Both computations and measurements showed similar spanwise velocity variations. At $\mathrm{S}=3.12$ station, the $\mathrm{V}_{\mathrm{s}}$ from the computations and experiment had approximately the same wave length, $\lambda$. However, the computations predicted a small amplitude at $\mathrm{S}=3.12$. The computations showed an increase in the amplitude of the $\mathrm{V}_{\mathrm{s}}$ variation at $\mathrm{S}=5.35$ but the experiments showed small amplitude of $\mathrm{V}_{\mathrm{s}}$ variation at $\mathrm{S}=5.35$. 


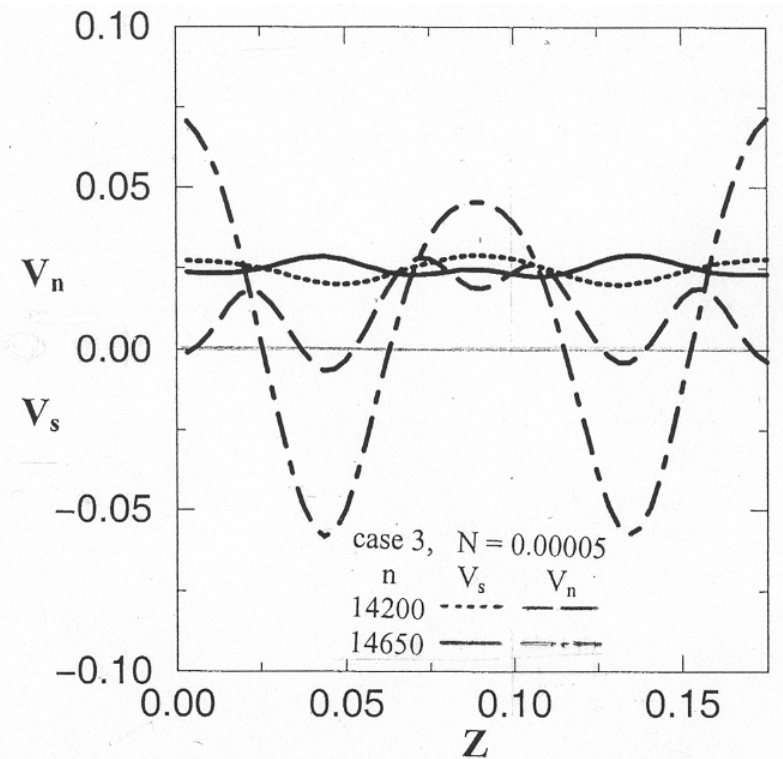

Fig 8 Span-wise variations of $V_{n}$ and $V_{s}$ at $S=3.12$
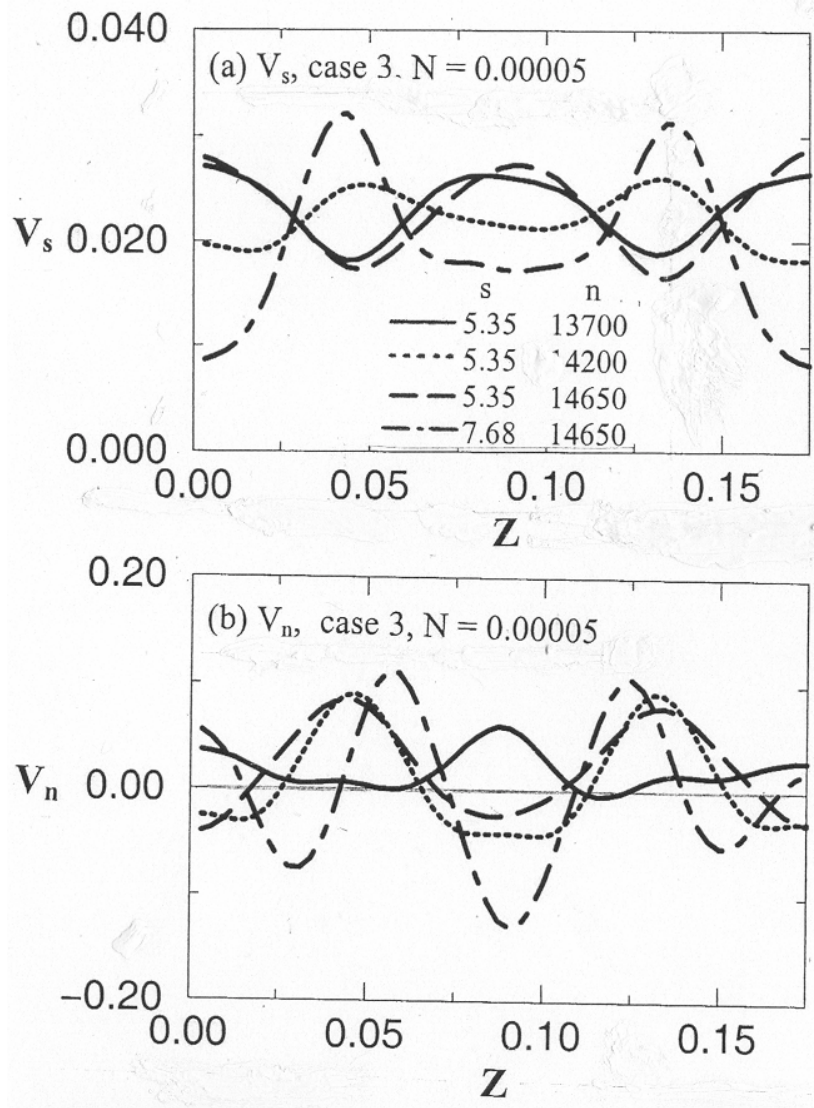

Fig 9 Span-wise variations of $V_{n}$ and $V_{s}$ at $S=5.35$ and 7.68 .
Some of the computational results (from case 3) of tangential and normal velocity components at the first cell centers were studied for the patterns of the velocity variations over the concave wall surface. The $\mathrm{Z}$ direction variations of $\mathrm{V}_{\mathrm{s}}$ and $\mathrm{V}_{\mathrm{n}}$, at two time iteration steps ( $\mathrm{n}=$ 14200 and 14650 ) and $S=3.12$ station were shown in Figure 8 . At $\mathrm{Z} \approx 0.05$ and $0.13, \mathrm{~V}_{\mathrm{n}}$ was high and directed towards the wall surface at $n=14650$ and this $V_{n}$ was associated with higher $V_{s}$ than its value at $n=14200$. At $Z$ $=0.088, V_{n}$ was directed away from the wall surface at these two time steps. $V_{n}$ was high at $n=14650$ and was associated with low $\mathrm{V}_{\mathrm{s}}$. These relationships among the velocity components agreed with the effect of upwash and downwash on the velocity variations (Figure 1) at the near surface locations The $\mathrm{Z}$ direction variations of $\mathrm{V}_{\mathrm{s}}$ and $\mathrm{V}_{\mathrm{n}}$ at $\mathrm{S}=5.35$ and $\mathrm{n}=13700,14200$ and 14650 and at $\mathrm{S}=$ 7.68 and $n=14650$ were shown in Figure $9 a$ and $b . V_{s}$ at $\mathrm{S}=5.35$ oscillated at these three time iterations (Figure 9a) and $V_{s}$ at $n=14650$ retained approximately its value at $n=13700$ with a different value at $n=14200$. The effect of the $V_{n}$ direction (upwash and downwash) on the $\mathrm{V}_{\mathrm{s}}$ value appeared at $\mathrm{n}=14650$ time step. At $\mathrm{S}=7.68$ station, $V_{n}$ (Figure $9 b$ ) changed its direction periodically at locations along the $\mathrm{Z}$ direction. However, the $\mathrm{V}_{\mathrm{s}}$ variation along the $\mathrm{Z}$ direction (Figure 9a) was not well correlated with the change in the $\mathrm{V}_{\mathrm{n}}$ direction (Figure $9 \mathrm{~b}$ ).

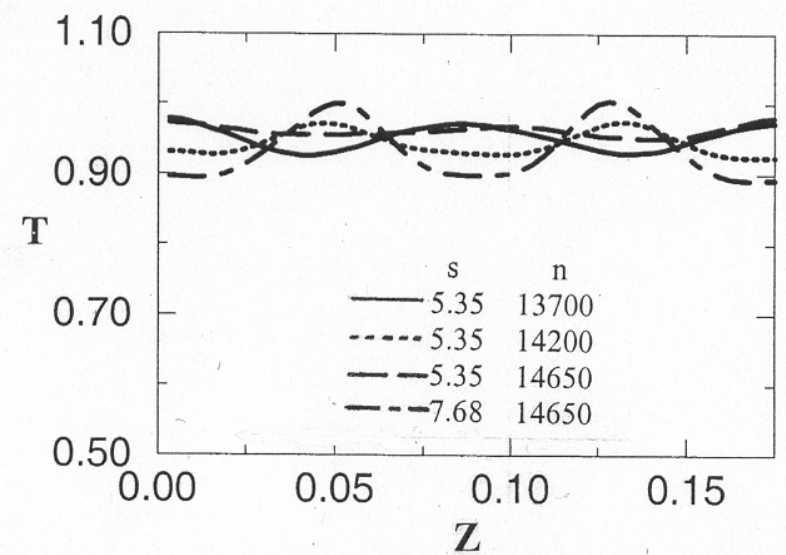

Fig 10 Span-wise Temperature variations at $S=\mathbf{5 . 3 5}$ And $S=7.68$

The span-wise variations of the static temperatures, obtained from the computations, at the first cell centers at $\mathrm{S}=5.35$ for $\mathrm{n}=13700,14200$, and 14650 and at the first cell centers at $S=7.68$ for $n=14650$ were plotted in Figure 10. The temperature at $\mathrm{S}=5.35$ with $\mathrm{n}=1370$ and 14650 and at $\mathrm{S}=7.68$ with $\mathrm{n}=14650$ all showed periodically span-wise variations. The temperature variation agreed well with patterns (Figure 2) of wall surface temperature obtained from the liquid crystal 
technique $^{5}$. The temperature at $\mathrm{S}=5.35$ also oscillated in terms of time steps at $n=13700,14200$, and 14650 .

Thus, the computations (case 3 ), with $\chi_{\mathrm{i}}=0.075$ and grid point dimensions of $205,61,57$, predicted experimental observations of the near surface velocity and temperature within a boundary layer developed along a concave wall surface. The concave wall surface induced vortices at the upstream stations $(\mathrm{S}<3)$. The calculated vortices induced upwash and downwash at near surface locations. Downwash increased the tangential velocity and upwash decreased the tangential velocity. The vortex broke down at the mid stream-wise stations $(\mathrm{S}=5.35)$. The association of vortices and the velocity components disappeared at downstream stations and unsteady three dimensional variations in the velocity and temperature occurred at the near wall surface locations.

\section{Method Application}

As a preliminary step to analyze the turbine blade flow with the method, it was used to compute (case 4) the near wall surface velocity and friction factors of flow over a concave wall with a downstream recovery flat wall surface ${ }^{6}$.

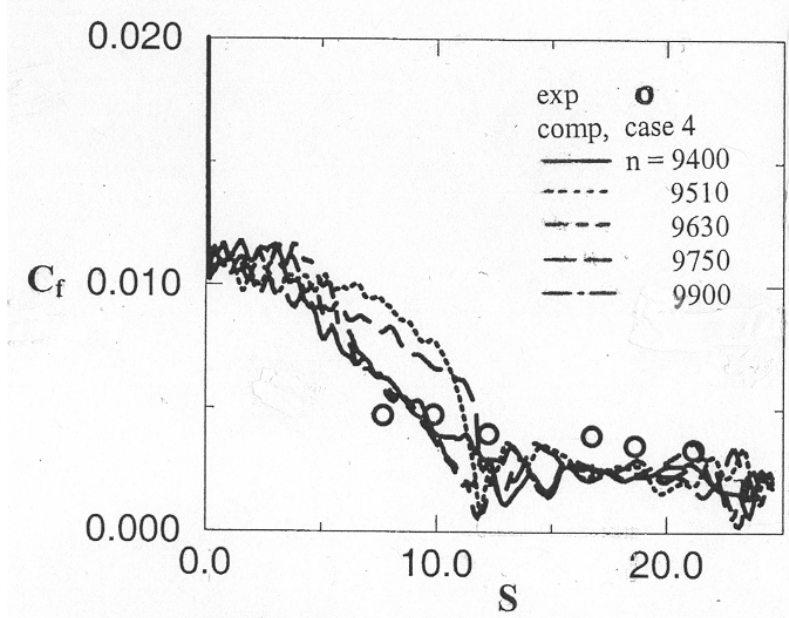

Fig 11 Stream-wise variations of $\mathrm{C}_{\mathrm{f}}$ at symmetric plane, $\mathrm{z} \approx 0$

Computed $\mathrm{C}_{\mathrm{f}}$ at $\mathrm{Z} \approx 0$ (near symmetric plane) and all $\mathrm{S}$ stations were shown in Figure 11. $\mathrm{C}_{\mathrm{f}}$ at five different time iteration steps within $9400<\mathrm{n}<9900$ were presented in this figure. $C_{f}$ values at 6 stream-wise stations from the experiment ${ }^{6}$ were also plotted in this figure to verify the accuracy of the $\mathrm{C}_{\mathrm{f}}$ calculations. The computed $\mathrm{C}_{\mathrm{f}}$ at $\mathrm{n}=$ 9400, 9630, and 9900 agreed well with the experimental $\mathrm{C}_{\mathrm{f}}$ at $\mathrm{S}=7.5,9.9$, and 12.2. The computed $\mathrm{C}_{\mathrm{f}}$ values at the flat wall surface $(\mathrm{S}>12.5)$ were lower than their experimental values. However, the computed $\mathrm{C}_{\mathrm{f}}$ at the flat wall surface was about $2.5 \times 10^{-3}$. This value was close to the friction factor of a fully developed turbulent boundary layer flow along a flat wall surface. At all $\mathrm{S}$ stations, the computed $\mathrm{C}_{\mathrm{f}}$ value was almost the same at $\mathrm{n}=9400$, 9630, and 9900. At $\mathrm{n}=9510$ and $9750, \mathrm{C}_{\mathrm{f}}$ values at the concave wall surface were higher than their values at $\mathrm{n}=$ 9400, 9630, and 9900. This indicated that $\mathrm{V}_{\mathrm{s}}$ at the near wall surface locations oscillated in terms of the time iteration step. As an example, the computed (case 4) $\mathrm{V}_{\mathrm{s}}$ and $\mathrm{V}_{\mathrm{n}}$ at $\mathrm{S}=3.35, \mathrm{Z}=0.077,0.175$, and 0.272 within $9300<\mathrm{n}<10000$ were plotted in Figure 12. Both $\mathrm{V}_{\mathrm{s}}$ and $\mathrm{V}_{\mathrm{n}}$ oscillated periodically in term of time iteration steps. $\mathrm{V}_{\mathrm{n}}$ also changed its direction periodically and showed downwash and upwash effects on $\mathrm{V}_{\mathrm{s}}$.



Fig $12 V_{n}$ and $V_{s}$ variations for $9300<n<10000$

The computed $\mathrm{V}_{\mathrm{n}}$ and $\mathrm{V}_{\mathrm{s}}$ values at $\mathrm{N}=0.00005$ locations along the $\mathrm{Z}$ direction at $\mathrm{S}=3.35$ and $\mathrm{n}=9490,9575$, 9663, and 9775 were shown in Figure 13(a) and (b). At n $=9490$ and 9663, $\mathrm{V}_{\mathrm{n}}$ directed away (upwash) from the wall surface and had approximately the same values at $n$ $=9490$ and 9663. At $\mathrm{n}=9575$ and 9775, $\mathrm{V}_{\mathrm{n}}$ directed towards (downwash) the wall surface and $V_{n}$ values were very close at all $\mathrm{Z}$ locations. $\mathrm{V}_{\mathrm{s}}$ values at $0.08<\mathrm{Z}<0.27$ oscillated at these four time steps. $\mathrm{V}_{\mathrm{n}}$ and $\mathrm{V}_{\mathrm{s}}$ at $0.08<\mathrm{Z}<$ 0.27 showed that positive $V_{n}$ was associated with low $V_{s}$ and negative $V_{n}$ was associated high $V_{s}$. This $V_{n}$ and $V_{s}$ relationship showed the vortices effects on the span-wise velocity variation. 

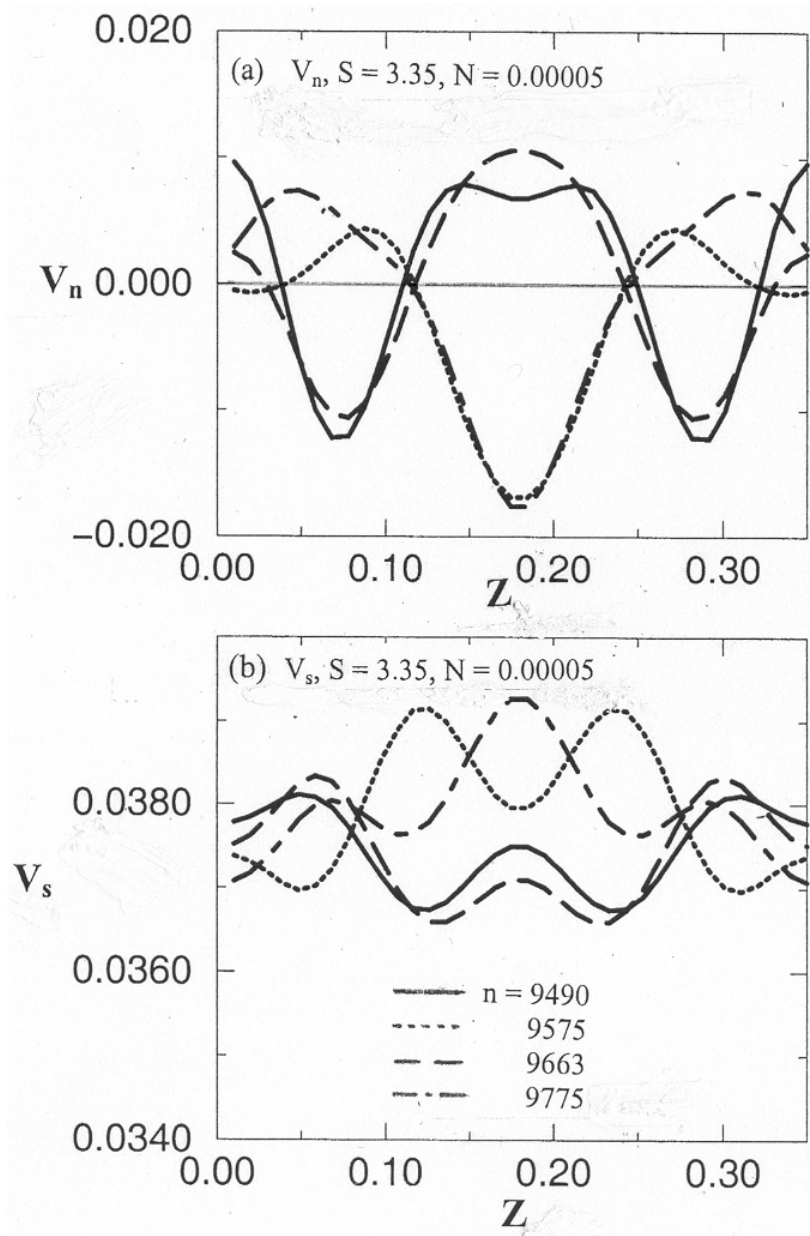

Fig $13 V_{n}$ and $V_{s}$ correlations for $9490<n<9775$

Computed $\mathrm{V}_{\mathrm{s}}$ values at $\mathrm{n}=9600, \mathrm{~N}=0.0032,0<\mathrm{Z}<$ 0.35 and $S=5.5$ and 7.7 were plotted in Figure 14 and they were compared with the velocity measurements from the experiment ${ }^{6}$. The computed $\mathrm{V}_{\mathrm{s}}$ values at $\mathrm{S}=5.5$ agreed well with the velocity measurements at $Z<0.15$ locations. The computed Vs oscillated along the $\mathrm{Z}$ direction, especially at $\mathrm{S}=7.7$ station, and the measurements showed only slight oscillation. However, the computations predicted well the experimental $V_{\mathrm{s}}$ values at $0.1<\mathrm{Z}<0.2$ and $\mathrm{S}=7.7$ locations.

Existing experiments ${ }^{9}$ measured the velocities at locations within very small distance from the wall surface at $S=$ 7.7, 9.9, and 12.2 stations. The computed $\mathrm{V}_{\mathrm{s}}$ values at $\mathrm{z} \approx$ $0.01,0.175$ and $\mathrm{n}=9600$ at locations within $\mathrm{N}<0.01$ and $\mathrm{S}=7.7,9.9$ and 12.2 were plotted in Figure 15 and were compared with velocity measurements. At $z=0.01$, the computed $\mathrm{V}_{\mathrm{s}}$ values agreed very well with the $\mathrm{V}_{\mathrm{s}}$ measurements at $S=7.7$ and 9.9. At these $S$ stations, the computations predicted high $\mathrm{V}_{\mathrm{s}}$ at $\mathrm{N}>0.0025$ and $\mathrm{Z}=$ 0.175 locations. The computed $\mathrm{V}_{\mathrm{s}}$ was reduced to small value at $\mathrm{S}=12.2$ and the $\mathrm{V}_{\mathrm{s}}$ profiles showed cross-stream inflection point profiles (Figure 1). The measurements showed only very small velocity reduction at $\mathrm{S}=12.2$ station. The difference could be due to the vortices effect on the $\mathrm{V}_{\mathrm{s}}$ computations. The vortices effects were not detected in the experiments.

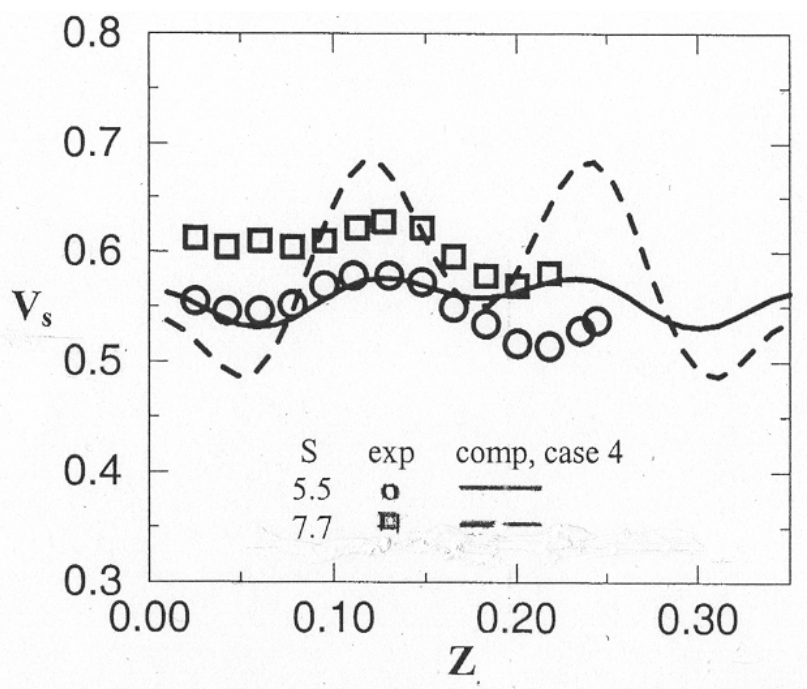

Fig 14 Span-wise variations of $V_{s}$ at $N=0.0032$ and $\mathrm{n}=9600$

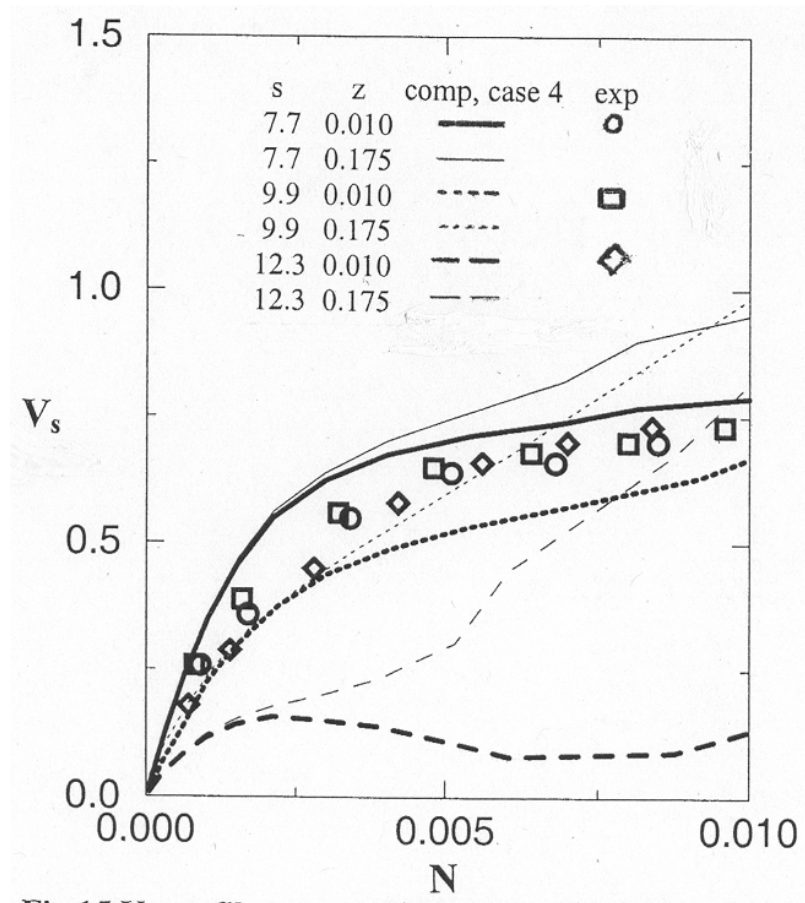

Fig $15 V_{s}$ profiles at $n=9600$ and $S=7.7,9.9$, and 12.3 


\section{CONCLUSION}

In an effort to establish a numerical computational method to investigate steadiness of turbine blade flow, the author used the time-stepping RANS numerical solver in the NASA Glenn-HT RANS code to predict the steadiness of the boundary layer flows with the effects of a concave wall and inlet turbulence. The NASA GlennHT RANS code, with two-equation turbulence models, was established for blade surface heat transfer studies. However, this author used a version of One-Equation Turbulence Model. This model accounts for the flow transition with vorticity at the wall surface. Realistic inlet turbulence parameter can also be assigned (see the APPENDIX) when the turbulence model is used in CFD work.

As a calibration of the numerical computational methods, computations were performed to predict the experimental results of the near surface velocity and temperature variations in a transitional boundary layer flow along a concave wall surface. With specific boundary conditions and computational grid, the computations predicted well the skin friction measurements at different stream-wise locations. The computed tangential and normal velocity components, at upstream locations, oscillated periodically as numerical time iteration progressed. The velocity components also exhibited span-wise periodic variation which agreed with the vortices induced upwash and downwash at span-wise locations. The velocity components at downstream stations did not show the coherent structure of vortices effects on the velocity components and agreed with the vortices broke down at downstream stations. The span-wise temperature variation, at downstream station, agreed with wall surface temperature patterns from experiments.

As a test of the present CFD methods to analyze the turbine blade flow, the computations were used to compute the friction factors and velocity variations at near surface locations of a boundary layer flow over a concave wall surface with a flat recovery wall surface. With specified boundary conditions and computational grid, the present computational results of friction factors converged to the measurements of friction factors. When the convergence was approached, the computed velocities at the upstream near surface locations exhibited vortex effects on tangential and normal components and the components varied periodically in terms of time iteration steps. The computations also predicted the measurements of the tangential velocity components at locations near the junction of the concave wall and flat wall surfaces.

\section{SUMMARY}

Wall curvature and inlet turbulence level play important roles in flow development over a turbine airfoil. As the boundary layer flow develops along a concave wall surface, Taylor-Gortler vortices may occur within the boundary layer flow and the flow can be steady, transitional, unsteady and turbulent. Existing experiments showed that combinations of concave wall curvature and flow inlet turbulence level induced vortices in the flow. Vortex formation and broke up caused transitional and unsteady three dimensional flow. This paper presented computational fluid dynamic studies of the inlet turbulence and wall curvature effects on the flow steadiness at near wall surface locations in boundary layers. The time stepping RANS numerical solver of the NASA Glenn-HT code and a one-equation turbulence model were used to perform the computations.

The present computational methods predicted, with reasonable accuracy, the velocity properties at near surface locations in a boundary layer flow with the effects of concave wall curvature and inlet turbulence. As time iteration proceeded, the computed friction factors and velocity values converged to their measurements in existing experimental studies. Periodic oscillations in the computed friction factors and tangential and normal velocity components were also found at large time iteration steps. The computed velocity components also showed the Taylor-Gortler vortices effects on the relations among the velocity components.

The numerical scheme was previously developed for the predictions of steady state heat transfer rate of turbine blade flows. The present computations used small local time step in the numerical scheme and single transport equation for turbulence modeling in the computations. The scope of the computations was mostly limited to the predictions of the near wall surface velocity properties in boundary lager flow with concave wall and inlet turbulence. However, the computations captured some interesting flow phenomena in terms of time stepping iteration. It was concluded that the present computational methods had the potential to analyze the effects of inlet turbulence and concave wall curvature on the steadiness of gas turbine blade flow. 


\section{APPENDIX}

Based on the original One-Equation turbulence transport equation ${ }^{3}$, the author wrote $^{1}$ the following equation, in terms of time, $t$, and orthogonal coordinates, $\mathrm{x}, \mathrm{y}$, and $\mathrm{z}$, to model turbulent eddy viscosity, $v_{\mathrm{t}}$.

$$
\begin{aligned}
& \frac{\partial}{\partial t}(\rho \tilde{v})+\frac{\partial}{\partial x}(\rho u \tilde{v})+\frac{\partial}{\partial y}(\rho v \tilde{v})+\frac{\partial}{\partial z}(\rho w \tilde{v}) \\
& =\frac{\partial}{\partial x}\left[\frac{\rho(v+\widetilde{v})}{\sigma} \frac{\partial \widetilde{v}}{\partial x}\right]+\frac{\partial}{\partial y}\left[\frac{\rho(v+\widetilde{v})}{\sigma} \frac{\partial \widetilde{v}}{\partial y}\right] \\
& +\frac{\partial}{\partial z}\left[\frac{\rho(v+\widetilde{v})}{\sigma} \frac{\partial \widetilde{v}}{\partial z}\right]+\rho C_{b 1}\left(1-f_{t 2}\right) \tilde{S} \widetilde{v} \\
& -\rho\left(C_{w 1} f_{w}-C_{b 1} f_{t 2} / \kappa^{2}\right)(\widetilde{v} / d)^{2}+\rho f_{t 1} \Delta u^{2}
\end{aligned}
$$

The above equation assumes that molecular viscosity $v$, depends only on local temperature and the empirical constant, $C_{b 2}$, in the diffusion terms of the original version was zero.

The eddy viscosity, $v_{t}$, is related to the working variable, $\widetilde{v}$, through the following relationships, $v_{t}=\tilde{v} f_{v 1}$

$f_{v 1}=\chi^{3} /\left(\chi^{3}+C_{v 1}^{3}\right)$

and

$$
\chi=\tilde{v} / v .
$$

The production term, $\widetilde{S}$, is given by

$$
\widetilde{S}=S+\left(\widetilde{v} / \kappa^{2} d^{2}\right) f_{v 2}
$$

$\mathrm{S}$ is the magnitude of the vorticity, $\mathrm{d}$ is the distance to the wall, and $f_{v 2}=1-\chi /\left(1+\chi f_{v 1}\right)$

The destruction function, $f_{w}$, is given by

$$
f_{w}=g\left(\frac{1+C_{w 3}{ }^{6}}{g^{6}+C_{w 3}{ }^{6}}\right)^{1 / 6}
$$

where $g=r+C_{w 2}\left(r^{6}-r\right)$

and $r=\widetilde{v} /\left(\widetilde{S} \kappa^{2} d^{2}\right)$.
The transition functions are

$$
\begin{aligned}
& f_{t 1}=C_{t 1} g_{t} \exp \left(-C_{t 2}\left(\omega_{t}{ }^{2} / \Delta u^{2}\right)\left(d^{2}+g_{t}{ }^{2} d^{2}\right)\right) \\
& f_{t 2}=C_{t 2} \exp \left(-C_{t 4} \chi^{2}\right)
\end{aligned}
$$

where $g_{t}=\min \left(0.1, \Delta u / \omega_{t} \Delta x\right)$.

In the transition functions, $\omega_{t}$ is the vorticity at the surface and $\Delta x$ is the grid spacing along the $\mathrm{x}$ direction. The velocity difference between a field point and the surface was $\Delta u$.

The turbulence model used the following set of empirical constants:

$$
\begin{aligned}
& C_{b 1}=0.1355, C_{b 2}=0.622, \sigma=2 / 3, \kappa=0.41 \\
& C_{w 1}=C_{b 1} / \kappa^{2}+\left(1+C_{b 2}\right) / \sigma, C_{w 2}=0.3 \\
& C_{w 3}=2, C_{v 1}=7.1, C_{t 1}=1, C_{t 2}=2, C_{t 3}=1.1 \\
& C_{t 4}=2 .
\end{aligned}
$$

It was also suggested that $\chi \approx 0.1$ be used for free stream condition. With the range of $\chi$ and equations (2), (3), and (4), the inlet turbulence level can be specified in terms of the molecular viscosity. With $\chi \approx 0.1$ and $\mathrm{C} v 1=7.1$ in equation (3), eddy viscosity much smaller than the molecular viscosity was used for free stream in the model.

The present author implemented ${ }^{1}$ the above turbulence model in the NASA Glenn-HT code to model the turbulence terms in the 3-dimensional compressible Navier-Stokes equations. 


\section{REFERENCES}

1. Wang, C.R., "Application of a Turbulence Model for Jet and Cross Flow Interaction," AIAA-2000-2655, Fluids 2000, June 2000, Denver, CO.

2. Arnone, A., Liou, M.S., and Povinelli, L.A., "Multigrid Calculation of Three Dimensional Viscous Cascade Flows," AIAA 9th Applied Aerodynamics Conference, 1991, Baltimore, MD.

3. Spalart, P.R. and Allmaras, S.R., "A one-equation Turbulence Model for Aerodynamic Flows," AIAA paper 92-439, Reno, NV.

4. Wang, C.R., "Preliminary Study of Vortices Effects on Flow Along a Concave Wall Surface," FD-ABS072, 9th International Symposium on Transport Phenomena and Dynamics of Rotating Machinery, 2002, Honolulu, HI.

5. Kim, J., Simon, T., and Russ, S.G., "Free-Stream Turbulence and Concave Curvature Effects on Heated, Transitional Boundary Layers," Transaction of the ASME, Journal of Heat Transfer, Vol. 114, 1992.
6. Kestoras, M.D. and Simon, T.W., "Hydrodynamics and Thermal Measurements in a Turbulent Boundary Layer Recovering From Concave Curvature," Journal of Turbomachinery, Vol. 114, 1992.

7. Jameson, A., Schmidt, W., and Turkel, E., "Numerical Solutions of the Euler Equations by Finite Volume Methods Using Runge-Kutta TimeStepping Schemes," AIAA Paper, No 81-1259, 1981.

8. Towne, C.E., Schwab, J.R., and Bui, T.T., "Proteus Three-Dimensional Navier-Stokes Computer CodeVersion 1.0," Volume 1-Analysis Description, NASA TM-106337, 1993.

9. Kestoras, M.D. and Simon, T.W., "Effects Of FreeStream Turbulence Intensity On A Boundary Layer Recovering From Concave Curvature Effects," ASME Paper, presented at the International Gas Turbine and Aeroengine Congress and Exposition, Cincinnati, Ohio, May 24-27, 1993. 
Public reporting burden for this collection of information is estimated to average 1 hour per response, including the time for reviewing instructions, searching existing data sources, gathering and maintaining the data needed, and completing and reviewing the collection of information. Send comments regarding this burden estimate or any other aspect of this collection of information, including suggestions for reducing this burden, to Washington Headquarters Services, Directorate for Information Operations and Reports, 1215 Jefferson Davis Highway, Suite 1204, Arlington, VA 22202-4302, and to the Office of Management and Budget, Paperwork Reduction Project (0704-0188), Washington, DC 20503.

\begin{tabular}{|l|c|c|c|}
\hline 1. AGENCY USE ONLY (Leave blank) & $\begin{array}{r}\text { 2. REPORT DATE } \\
\text { June } 2003\end{array}$ & $\begin{array}{r}\text { 3. REPORT TYPE AND DATES COVERED } \\
\text { Technical Memorandum }\end{array}$ \\
\hline 4. TITLE AND SUBTITLE & 5. FUNDING NUMBERS
\end{tabular}

Study of Unsteady Flows With Concave Wall Effect

6. AUTHOR(S)

WBS-22-713-82-43

Chi R. Wang

7. PERFORMING ORGANIZATION NAME(S) AND ADDRESS(ES)

National Aeronautics and Space Administration

John H. Glenn Research Center at Lewis Field

Cleveland, Ohio 44135-3191

8. PERFORMING ORGANIZATION REPORT NUMBER

E-13977

9. SPONSORING/MONITORING AGENCY NAME(S) AND ADDRESS(ES)

National Aeronautics and Space Administration

Washington, DC 20546-0001

10. SPONSORING/MONITORING AGENCY REPORT NUMBER

NASA TM-2003-212394

AIAA-2003-4073

\section{SUPPLEMENTARY NOTES}

Prepared for the 21st Applied Aerodynamics Conference sponsored by the American Institute of Aeronautics and Astronautics, Orlando, Florida, June 23-26, 2003. Responsible person, Chi R. Wang, organization code 5820, 216-433-5865.

12a. DISTRIBUTION/AVAILABILITY STATEMENT 12b. DISTRIBUTION CODE

Unclassified - Unlimited

Subject Category: 34

Distribution: Nonstandard

Available electronically at http://gltrs.grc.nasa.gov

This publication is available from the NASA Center for AeroSpace Information, 301-621-0390.

13. ABSTRACT (Maximum 200 words)

This paper presents computational fluid dynamic studies of the inlet turbulence and wall curvature effects on the flow steadiness at near wall surface locations in boundary layer flows. The time-stepping RANS numerical solver of the NASA Glenn-HT RANS code and a one-equation turbulence model, with a uniform inlet turbulence modeling level of the order of 10 percent of molecular viscosity, were used to perform the numerical computations. The approach was first calibrated for its predictabilities of friction factor, velocity, and temperature at near surface locations within a transitional boundary layer over concave wall. The approach was then used to predict the velocity and friction factor variations in a boundary layer recovering from concave curvature. As time iteration proceeded in the computations, the computed friction factors converged to their values from existing experiments. The computed friction factors, velocity, and static temperatures at near wall surface locations oscillated periodically in terms of time iteration steps and physical locations along the span-wise direction. At the upstream stations, the relationship among the normal and tangential velocities showed vortices effects on the velocity variations. Coherent vortices effect on the velocity components broke down at downstream stations. The computations also predicted the vortices effects on the velocity variations within a boundary layer flow developed along a concave wall surface with a downstream recovery flat wall surface. It was concluded that the computational approach might have the potential to analyze the flow steadiness in a turbine blade flow.

14. SUBJECT TERMS

15. NUMBER OF PAGES

Unsteady flow; Computational fluid dynamics; Turbulence model

\begin{tabular}{|c|c|c|}
\hline $\begin{array}{c}\text { 17. SECURITY CLASSIFICATION } \\
\text { OF REPORT } \\
\text { Unclassified }\end{array}$ & $\begin{array}{c}\text { 18. SECURITY CLASSIFICATION } \\
\text { OF THIS PAGE } \\
\text { Unclassified }\end{array}$ & $\begin{array}{c}\text { 19. SECURITY CLASSIFICATION } \\
\text { OF ABSTRACT } \\
\text { Unclassified }\end{array}$ \\
\hline
\end{tabular}

